\title{
The Textile Industry of Eastern Africa in the Longue Durée
}

\author{
William G. Clarence-Smith
}

\subsection{INTRODUCTION}

Historians are divided over the issue of the role of textiles in the economic development of eastern Africa, defined here as stretching from the Sudan to South Africa. Ravi Palat and Immanuel Wallerstein claim that India "deindustrialized" its Indian Ocean periphery by exploiting advanced textile techniques and cheap labor (Palat and Wallerstein 1999, 36-7). Similarly, John Mack and Pedro Machado contend that Indian imports fatally undermined a fragile textile sector in eastern Africa, long before Lancashire and New England cottons flooded in from the mid-nineteenth century (Machado 2005, 91-151, 2009, 167; Mack 1993, 303-4). Michael Pearson recognizes that Indian cloth penetrated deep into the markets of early modern eastern Africa, but he poses a crucial counterfactual question: Would the performance of African textiles have been better or worse without imports from South Asia? (Pearson 1998, 121-2).

The fact that textile production grew in South Asia's oceanic periphery from the mid-seventeenth to the mid-nineteenth century, including in eastern Africa, argues against the position adopted by Palat, Wallerstein, Mack, and Machado. Trade proved to have generally positive rather than negative consequences. While locally produced cloth was only episodically competitive overseas, it had substantial internal markets in Africa. South Asian artisans emigrated little, but they provided models to imitate. Specialized trade diasporas, often South Asian in composition, supplied information, credit, shipping, commercial facilities, and intermediate goods for further transformation, such as colored yarn and plain cloth (Clarence-Smith 2009, 2011). Thus eastern Africa was not a captive market for South Asia, but rather a partner in the development of textile production. 
That said, eastern Africa's textile industry remained far weaker than that of South Asia, and there is absolutely no indication that any part of Africa was heading for an industrial revolution on European lines (Parthasarathi 2011). There is some evidence for tendencies toward proto-industrialization, marked by the specialization of workers, the creation of workshops, and market relations of a putting-out type. However, eastern Africa was very sparsely populated, with a few exceptions, and neither the productivity of agriculture nor per capita incomes were favorable to widespread proto-industry.

Colonial and postcolonial leaders usually failed to recognize the strengths of this budding artisanal sector, and their policies ensured that the protoindustrial path to economic development was even less likely to be followed. All their energies eventually went into developing modern mills that proved to be "white elephants." Nevertheless, rather surprisingly, the artisanal sector survived this misguided modernizing onslaught, and is at last being given some official attention in our own times.

\subsection{ARTISANS OF EARLY MODERN MADAGASCAR}

European newcomers in the sixteenth century considered Malagasy textiles to be the finest in the region (Grandidier 1928, 168; Rita-Ferreira 1999, 117-18). The great island displayed more diverse techniques, wove a greater variety of textile fibers, and employed a wider palette of colors than any other part of eastern Africa (Fee 2002; Mack 1987, 1989). Cotton cultivation dominated in the dry southwestern zone of Madagascar, while forested lowland zones were chiefly the domain of raffia. Wild silk prevailed in many places, and hemp, banana, spun bark, and plaited reeds played a minor role. Fibers were sent from the coastlands to the densely peopled central plateau for weaving, and cloth moved the other way (Campbell 2005, 31-2; Fee 2002, 40, map 2, 2005, 94).

Pedro Machado claims that South Asian competition was negatively affecting Madagascar's textile economy by the 1780s, citing sales of South Asian cloth on the central plateau at that time (Machado 2009, 168). However, the mere mention of markets for Indian textiles in the interior does not mean that local production was being undermined. Yemen may have ceased to purchase Malagasy cloth from the thirteenth century, but East Africa remained a significant external market (Baldry 1982, 17; Kent 1970, 69; Newitt 1995, 28). Moreover, European vessels took local cloth to the newly settled Mascarene Islands (Mauritius and Réunion) from the mid-seventeenth century (Ellis 1838, I, 68; Fee 2005, 98; Larson 2000, 52). 
In any event, Madagascar's internal market for its own cloth showed no signs of weakening in the late eighteenth and early nineteenth centuries. Contemporary texts and oral traditions depict a flourishing and vital textile sector. A French traveler on the Malagasy central plateau in 1777 opined that women were so busy weaving that they left domestic chores to men, pointing to a growing division of labor. An 1826 report noted that local cloth was competing well with the imported variety, and that every woman in the country was busy weaving. Indeed, many women wove full time, ranging "from the King's wives to the slaves" (Fee 2005, 94; Larson 2000, $124,128-9,145)$. In 1838, one observer wrote about textiles as "the most general employment of the people," after rice cultivation, and gave a detailed description of spinning and weaving (Ellis 1838, I, 277, 282, 324-7).

Changing Malagasy attitudes toward rituals and politics boosted weaving. After Radama II had been murdered, partly for ordering his subjects to dress in Western clothes in 1861, it became mandatory to wear locally woven lamba for ritual occasions (Fee 2002, 61, 90, note 29). Burial ceremonies became more elaborate, involving greater quantities of cloth. In the Merina and northern Betsileo lands, there was a second solemn burial of dried remains of the deceased, which were wrapped in cloth. Only handspun and handwoven textiles appear to have been acceptable for these purposes (Bronson 2004, 166; Deschamps 1947, 121; Fee 2002, 62-3; Larson 2000, 128-9; Schaedler 1987, 428). Local cloth was also entrenched in the giving of gifts up and down the social hierarchy (Fee 2002, 64-7).

\subsection{ARTISANAL TEXTILES IN EARLY MODERN NORTHEASTERN AFRICA}

Northeastern Africa had a narrower range of products than Madagascar, almost entirely restricted to white cottons. However, these were of fine quality and were produced in considerable and growing quantities. Moreover, value was added by interweaving or embroidering with imported colored yarn.

The origins of cotton weaving were most ancient in Nubia, although cotton cultivation itself probably only dated from the beginning of the second millennium CE. Sudan's Blue Nile regions of Sennar and Damar were noted for their output of dammar, plain white cloth (Coquet 1993, 141-2; Lamb 2005, 107-8; Werbeloff 1987, 155). By the mid-nineteenth century, dammar was sold, given for marriage payments, paid as tribute, and used as currency (Ewald 1990, 72-3, 76, 87, 147-8). On the eve of colonial rule, women did the spinning, with Darfur enjoying a particular reputation, while men wove. The Jazirah (Gezira) region supplied dammar to Omdurman, where 
tailors turned it into the national costume. However, the best dammar was imported from Ethiopia, while printed cottons came from the wider world (Wingate 1986, 210, 380-2).

Ibn Battuta noted as early as the fourteenth century that Mogadishu's "unequalled" cotton textiles were exported "to Egypt and elsewhere" (Gibb $1962,374)$. Although exports to Egypt had ceased by early modern times, Somalia's Benadir coast continued to send cotton wares to other parts of eastern Africa into the twentieth century. Exports by sea were estimated at three hundred sixty thousand to three hundred eighty thousand pieces a year in the 1840s, and much cloth also went inland into southern Ethiopia (Alpers 1983, 77-89; Reese 1996, 95-6). Mogadishu contained around a thousand weaving households in the 1840s, with smaller numbers in other Benadir towns, and raw cotton was imported from India. These textiles found their main market in southern Ethiopia, but were still regularly sent by sea to Mombasa and north Somali ports (Guillain 1856-7, II, 531-2, 535 and III, 148-9, 172, 323).

Highland Christian Ethiopia produced similar white cottons for its own densely settled territory (Pankhurst 1968, 257-60; Schaedler 1987, 93-9, 396-423). Gondar and Axum, in the north, were traditional centers of production, together with Adowa, Ankobar, and Harar (Lamb 2005, 108; Pankhurst 1968, 257). Reports of travelers from the sixteenth century suggest that cotton cloth was slowly becoming the normal form of dress, gradually replacing skins and hides. Men were said to have adopted cloth before women, and "Semitic" peoples before others (Simoons 1960, 186-7).

Ethiopia's plain white material was made into undergarments, shawls, and turbans, whereas more colorful and elaborate stuffs were typically imported from South Asia (Burton 1894, II, 16-17; Wylde 1901, 246-8). Although vegetable dyes were employed to a limited extent, Ethiopians commonly unraveled imported Indian cloths to obtain colored weft, which they used to decorate the borders of their cloth (Pankhurst 1968, 260). Europeans were impressed by the "closeness, warmth and durability" of this Ethiopian cloth. Male weavers did not usually grow crops, pointing to labor specialization (Darkwah 1975, 145-6). Women spun, as well as embroidering plain cloth (Pankhurst 1968, 32). By the 1840s, some six hundred women were spinning in the imperial palace to supply court weavers (Darkwah 1975, 146).

\subsection{ARTISANAL TEXTILES IN THE "SWAHILI WORLD"}

To the south, the production of cotton textiles and a little silk was best established in Swahili port cities, from Pate (modern Kenya) to Sofala 
(modern Mozambique) (Newitt 1987, 203, 206-7). Spindle whorls occur in the archaeological record of Muslim coastal settlements from the tenth century (Horton 1996, 337-41; Kjekshus 1977, 106). Portuguese documents suggest a growth spurt during the fifteenth century, and that even slaves wore a piece of locally woven blue or white cloth from waist to knees. The Portuguese also noted that imported Gujarati stuffs, especially blue ones, were unraveled to obtain colored yarn, for example in Sofala and Pate, although indigo dyeing was practiced in places (Newitt 2002, 31-3; Prestholdt 1998, 24-5, 33).

The Kirimba (Querimba) islands, off the coast of northern Mozambique, produced a milwani cloth that was dyed with local indigo, and cotton was sometimes mixed with imported silk yarn. Milwani cloth was sold widely in eastern Africa during the sixteenth century, and was one of the "cloths of the land" that Portuguese traders eagerly sought for local commercial operations. However, it was no longer mentioned in a report of 1634 (Newitt 1995, 189-92, 2002, 125, 127-30; Prestholdt 1998, 27-30). That said, its demise was probably due to raiding, provoking the migration of artisans (Newitt, personal communication). As weaving cotton in the wider Rovuma region continued, artisans simply seem to have moved out of the vulnerable islands (Kjekshus 1977, 107). This episode does not, therefore, prove the thesis of underdevelopment.

Offsetting collapse in one area was the rise of new industries elsewhere. Thus Zanzibar only became a center of textile production after the sultans of Oman moved their main residence to the island in the early nineteenth century (Guillain 1856-7, III, 342). Cotton weaving grew there from the 1850 s, conducted in the open air. The wares of local weavers could be inspected on the pavements of the town in the 1860s (Kjekshus 1977, 105-6).

Most East African output was machira, which was made into hammocks, litters, blankets, cloaks, and belts (Davison and Harries 1980, 181-91, note 23). This was a coarse, unbleached cloth, a kind of cheap and durable homespun. Richard Burton criticized its "loose texture" and averred that "when it is dry it is rough and unpleasant, when wet, heavy, comfortless as leather, and it cannot look clean, as it is never bleached" (Burton 1860, II, 311, cited in Kjekshus 1977, 108). However, machira was widely traded, notably in exchange for gold dust on the Zimbabwean plateau (Alpers 1975, 24-5, 55; Newitt 1995, 28, 66, 75, 78, 94, 141, 214, 232, 239). The cloth was also used for currency, tax, bride price, and booty, and as an index of wealth and prestige (Davison and Harries 1980, 187). 
Isolated tax figures suggest that the cost of machira roughly halved in the eighteenth century, pointing to increasing productivity (Rita-Ferreira 1999, 118). Portuguese reports indicate that output was rising, and that the cloth continued to find a ready market on the Zimbabwean plateau (Bhila 1982, $122,131)$.

Most striking, machira production survived deliberate Portuguese attempts to suffocate it. From 1750, colonial officials considered that local weaving was reducing potential cloth imports from India, and thus negatively affecting tax revenues (Isaacman 1972, 66, 73-5, 199, 201). In 1750, the Junta do Comercio (Board of Trade) therefore suggested banning the cultivation of cotton in the lower Zambezi valley. This was judged to be unenforceable, as was an equally impractical scheme of 1753 to buy up all available raw cotton to sell it in India and China (Lobato 1957, 2412; Machado 2005, 110). In the event, the Portuguese proved incapable of stifling the production and sale of machira cloth (Mudenge 1988, 187). Moreover, the mixed-race lords of the lower Zambezi's prazo estates undermined the stance of Portuguese officials, as they demanded machira cloth as tribute from their African "serfs" (colonos) (Isaacman 1972, 66; Newitt 1995, 232, 239).

In any event, machira cloth production was still flourishing in the prazo region in the mid-nineteenth century, when David Livingstone noted that it was preferred to imports for many purposes (Alpers 1975, 25, 35, note 86). Indeed, imported yarn, initially from North America, allowed artisans to weave "lighter and finer cloths." By the 1890s, imported colored yarn enabled the production of new intricately patterned designs, perhaps influenced by Malagasy traditions (Davison and Harries 1980, 181-3, 189; Mack 1993, 303-4).

Cotton in the interior of East Africa faced much competition from bark, raffia, leather, and skins (Alpers 1975, 16, 21; Beinart 1982, 24-5; Cuypers 2004; Darish 1989, 117-40; Gillow 2003; Picton and Mack 1989, 33-43, 83-90, 131; Vansina 1998). Nevertheless, there was patchy spinning and weaving of cotton, from the Great Lakes down to what are today the northern Transvaal and Natal. Wild cotton frequently provided the raw material, although there was some cultivation (Alpers 1975, 16, 21-2, 25; Davison and Harries 1980, 175-81, 187). Richard Burton reported in 1860 that he found looms in every village, and another traveler wrote that he found two to three looms in each village in 1891. Weavers in the center of today's Tanzania produced striped and checked materials in yellow and black. Around 1900, the Haya, to the west of Lake Victoria, had 
only just learned how to weave from their Nyamwezi neighbors, and were experimenting with new types of cloth (Kjekshus 1977, 107-9).

\subsection{EARLY MODERN TECHNOLOGY AND PRODUCTION SYSTEMS}

Textile technology remains the least researched aspect of the early modern story. The oft-repeated mantra that methods of production stagnated in Africa is clearly incorrect, even if economic historians find few or no mentions of techniques in documents, and archaeologists lament the perishable nature of wood. Technical change did not necessarily imply more intricate designs or weaves, the interest of art historians, but rather faster production, in greater quantities, more cheaply, and in more varied formats. However, such techniques required some investment and training, and the equipment generally became less portable.

Traders were one probable source of technical change. They specified designs, provided market information, controlled quality, purchased finished textiles, and shipped them to near and distant markets. Thus Indian and Portuguese traders commercialized machira together with Indian cottons (Antunes 1992, 127; Newitt 1995, 28; Prestholdt 1998, 283, note 111). Nyamwezi traders, from today's central Tanzania, were active over a wide area during the nineteenth century, spreading techniques of cotton weaving to new regions (Kjekshus 1977, 108).

There were occasional examples of putting-out arrangements, and of merchant-owned workshops. In sixteenth-century Madagascar, where Portuguese and Arab merchants competed keenly for local textiles, cloths were woven to order in individual homes in the north of the island (Kent 1970, 69; Newitt 1995, 28; Prestholdt 1998, 30). Wealthy Arab and Somali merchants of the Benadir coast owned textile workshops, although they were far from dominating production (Cassanelli 1988, 312).

Coerced labor was common in workshops. Slavery had advantages in terms of training and retaining skilled labor, and Muslim scholars frowned on other forms of compulsion (Clarence-Smith 2006). Slaves thus manned the royal workshops of Tasi, in the Sudan, in 1839 (Ewald 1990, 87).

However, slavery interacted with other forms of labor. Most Somali weavers in the 1840s were free, albeit of low caste, weaving full time and buying their food on the market, and assisted by slaves, family members, and clients (Alpers 1983, 81, 84; Guillain 1856-7, II, 531; Reese 1996, 96-8). Unlike spinning, a prestigious occupation, weaving in Christian Ethiopia was allocated to Muslims, Jews, and those of low caste (Levine 1974, 56-7; 
Pankhurst 1968, 32, 40-1, 257-9). Men wove on the African mainland, whereas women did so in Madagascar, and women tended to dominate spinning everywhere (Kjekshus 1977, 109; Levine 1974, 113, 153; Mack 1989, 21; Schaedler 1987, 396-423).

Spinning wheels speeded up and cheapened the production of yarn, albeit at some cost in quality (Kuhn 1988). The evidence is sparse for eastern Africa, but the dynamism of Somalia's Benadir workshops was due partly to wheels, which produced four types of yarn in the 1840s. No date is given for their adoption, and they were probably simple spindle-wheels, lacking the crank, treadle, and flyer that enhanced the productivity of Saxon wheels (Guillain 1856-7, II, 532). As for Ethiopia, East Africa and Madagascar, they remained wedded to the hand spindle (Alpers 1975, 24-5; Grandidier 1928, 167; Kjekshus 1977, 106, 108; Pankhurst 1968, 258). In the Rukwa valley in 1899, in modern Tanzania, men spun with a "long spindled spool," rubbed between the palm of the hand and the thigh (Kjekshus 1977, 107-9). Christian missionaries tried to introduce spinning wheels to Madagascar in 1822, but the technique failed to take root after an English artisan returned home (Ellis 1838, I, 324, 327). Ambitious water-driven machines proved ill adapted to Malagasy conditions, and were rapidly abandoned (Fee 2002, 90, note 14).

Foot-operated treadles, lifting and lowering two fixed heddles, freed the weaver's hands to work more rapidly, and pit looms fitted with such treadles appeared in the settled communities of the Middle East and South Asia from around the beginning of the Common Era. Pits reduced the size of the wooden frame containing the loom and kept the yarn moist, thus less likely to break. As pit looms in northeastern Africa are generally of the Persian rather than Egyptian type, they probably came from the east (Lamb 2005, 98-107, 111-56; Roth 1977). Pit looms were standard by the nineteenth century in settled regions of northeastern Africa, spreading down into what is today northern Kenya (Alpers 1983, 80; Gillow 2003, 160-1; Lamb 2005, 107; Pankhurst 1968, 259-60; Roth 1977, 62-3).

King Tewodros (Theodore) of Ethiopia sought to improve looms, asking Queen Victoria to send artisans. A Protestant missionary arrived in 1855 for this purpose, and Swiss artisans followed (Bates 1979, 30, 55, 68). A photograph, taken in Gondar around 1900, depicts a large "tie-back" form of pit loom, typical of greater Syria and Egypt, which allowed for the weaving of longer and wider pieces (Lamb 2005, 107-10, 140, and plate 96). Such improved pit looms were probably introduced by diasporic traders rather than by European experts.

A kind of double-heddle loom was adopted in eastern Madagascar, seemingly in the eighteenth century. The northeastern coast employed such 
looms by around 1800 , and the technique spread some way down the coast. Moreover, Merina weavers of the island's central plateau displayed knowledge of this technique of weaving at a later period, even though they no longer practiced it. When the Betsimisaraka of the east coast employed a single fixed heddle, they lashed it to the rafters, as in the Persian Gulf (Mack 1987, 84-5, 1989, 21-2, 29-31). A youth trained in England ran a guild that "wove cotton on mechanical looms" from 1826 on Madagascar's plateau, but this missionary initiative failed (Fee 2002, 88-90, notes 14-15).

East Africa, south of the Horn, as well as much of Madagascar, employed the simple horizontal ground loom, adapted from that of Middle Eastern Bedouins. With its fixed single heddle, it was quick and easy to disassemble (Hecht 1989, 61-5; Lamb 2005, 1-6, 62). Ground looms were not necessarily as rudimentary as they are sometimes depicted, however. When the White Fathers sought to revive weaving in the Great Lakes region, one difficulty they faced was that local looms were "very complicated and of a delicate construction" (Kjekshus 1977, 80). Moreover, ground looms wove cloths that were wider than those of West Africa (Davison and Harries 1980, 1817; Lamb 2005, 31-3; Roth 1977, 40). Possibly reflecting the prevalence of raiding, miniature looms appeared in the interior of Central Africa, raised from the ground, and worked from the side (Lamb 2005, 32).

Other types of loom were occasionally found. Southern Madagascar had Southeast Asian looms, with the warp tensed by the use of a backstrap fitted on a seated weaver (Ellis 1838, I, 325; Fee 2005, 94; Grandidier 1928, 167; Mack 1987, 84-6, 1989, 22-32). Vertical or oblique looms, with a single heddle, existed in forested regions, generally confined to weaving raffia (Schaedler 1987, 65; Vansina 1998, 267). They may have been related to Egypt's vertical "Coptic loom," warp-weighted and with one fixed heddle (Lamb 2005, 61-3, 69, 72-3, 83, 86-8, 91).

Little colored cloth was produced outside Madagascar, but indigo dyeing was practiced in places, perhaps reflecting Arab traditions (Newitt 2002, 31-3; Prestholdt 1998, 24-5, 33). More significant, an anonymous author noted in the mid-eighteenth century that the Malagasy were imitating cloth from Bengal and the Coromandel Coast, suggesting incipient painting or printing (Peers 2004, 145).

\subsection{THE PERSISTENCE OF ARTISANAL TEXTILES IN THE "AGE OF EMPIRE"}

David Edgerton has argued persuasively that new technologies rarely simply displace old ones. Rather, novel techniques lead to resistance and adaptation 
(Edgerton 2008). Tax policies led to the underreporting of Africa's artisanal output, while indirect rule and local rituals maintained a culturally protected niche for handmade textiles (Renne 1995, 128-43). Whereas hand spinning was adversely affected by imports of factory-made yarn, weavers, dyers, and tailors viewed imports of yarn, plain cloth, and chemical dyes as a godsend. Moreover, new modes of transport extended local markets (Johnson 1978; Munro 1984, 62-3). Intermediate goods for textile artisans only came from the West for a brief period. Favored by the provisions of the Congo Free Trade Zone set up in 1885, Indian yarn and cloth flooded into eastern African markets from the 1890s, followed by Japanese products after 1914 (Clarence-Smith 1989a, 176, 1989b).

New or reconstructed crafts emerged during the colonial period (Munro 1984, 63). Tailoring was not entirely novel, but it changed out of all recognition in response to treadle-powered and electric sewing machines, employed in households and workshops (Godley 2001). The embellishment of cloth by hand also flourished, as embroidery and lace came to be traded on a large scale around the globe (Clarence-Smith 2004, 449-51).

The Benadir coast of southern Somalia is the best-studied case of artisanal production in the Age of Empire. From around the 1880s, imported machine-made yarn, increasingly chemically dyed, became a significant intermediate good for local weavers (Alpers 1983, 87-92). Somalis still preferred locally woven to imported cloth in the 1890s, and weaving in Mogadishu was "flourishing," with substantial imports of yarn (Cattelani 1897, 67, 72-3, 88-9, 135; Robecchi-Bricchetti 1899, 618-20). South Asian yarn quickly replaced the Western product. Aden received nearly 2.5 million pounds of yarn from British India in 1894-5, much of which was redistributed along the Somali coast (Great Britain 1896, 46, 56). Exports of Benadir cloth continued, even as imports of European cloth grew (Chiesi 1909, 347-53).

Commercial disruptions caused by the First World War led to a renaissance in Somali weaving, with men taking up the craft in substantial numbers. India was the chief source of imported yarn, with Japan of growing importance (Alpers 1983, 87-93). A report of 1920 noted that "a few hundred" looms were active in Mogadishu alone, worked by men. Other towns along the Benadir Coast also produced cloth, notably Merka, and there were exports to Mombasa and Zanzibar. Furthermore, women could still be seen spinning, despite imports of machine-made yarn (Stefanini 1922, 39). As late as the 1950s, more than one thousand households wove on the Benadir coast. Local textiles had become prestige goods for special occasions. Merchants provided yarn in a putting-out system, decried by Marxists 
as rank exploitation (Alpers 1983, 93-7). Somalia also exported artisanal caps and shawls to neighboring countries (Administration Italienne 1954, 79-80).

From the late nineteenth century, India supplied yellow and blue yarns for Ethiopian weavers, while grey, unbleached cloth came sequentially from North America, India, and Japan (Pankhurst 1968, 261, 402-4, 407-8, 416). The sector remained buoyant after the devastation caused by the Italian occupation of 1935-41 (Levine 1974, 113). In the early 1950s, women of the northwest spun white cotton yarn with spindles, while colored yarn was imported. Male indigenous Muslims worked in pit looms, but there were also itinerant weavers, who carried a light loom on their shoulder (Simoons 1960, 187). In Jimma, in the southwest, plain white shawls for men and women were the main product, with weaving relegated to men of low caste (Lewis 2001, 53-4).

Sudanese weavers continued to produce plain white dammar. Indeed, the introduction of new strains of cotton, aimed at boosting exports of raw materials, may have had the unintended consequence of improving the quality of yarn for local weavers (Issawi 1966, 479, 484). Local cloth held its own despite rising imports of cotton textiles, which accounted for about a quarter of the colony's total import bill at the time of the First World War (Great Britain 1920, 136, 148).

French officials predicted the imminent demise of handweaving in Madagascar after the conquest of 1896, but some French people sought to revive local crafts. A school of applied arts, set up in 1925, preserved cloths that were no longer fashionable, and contributed to the prestige of handweaving (Fee 2002, 68-9, 74-5, 81). A revival of weaving during the interwar years also served the purpose of stocking colonial exhibitions (Peers 1995, 47). Simultaneously, wearing local lamba became a sign of opposition to Westernization (Fee 2002, 61). Malagasy weavers worked with imported yarns in the 1920s, as well as the locally spun article (Kusimba, Odland, and Bronson 2004, 34, introduction by Kusimba, citing Ralph Linton).

Various authors similarly proclaimed the death of handmade textiles in East Africa (Davison and Harries 1980, 189-91; Pearson 1969, 124; Silver 1984, 44-5; Swainson 1980, 26). However, Helge Kjekshus notes that Rukwa cotton textiles, in Tanganyika, "defied extinction largely through the patronage of the Christian missions." Officials also stimulated production to combat shortages of cloth during the Second World War (Kjekshus 1977, 109 (quote), and 80, 106-9). Machira cloth production persisted in the lower Zambezi valley, and photographic and descriptive evidence of weaving across the Central African plateau was common until the First World War 
and even later (Davison and Harries 1980, 181, 185). Moreover, Christian missionaries made considerable efforts to teach Western methods of spinning, weaving, and sewing, for example in Southern Rhodesia (Zimbabwe) (Jeater 2007, 105, 146, 158).

Indian mills became major suppliers of grey and bleached plain cotton cloth to eastern Africa from the 1890s (Pirio 1982, 174-5). From the 1890s, some of the plain cloth was locally printed, as South Asian merchants in Swahili towns employed wooden blocks, on the Indian model, to print popular kanga. These were two-piece rectangular wrappers for women, with written mottos (Fair 2001, 68, 80; Hilger 1995, 44-5; Zawawi 2005, 16). Printing blocks were increasingly consigned to museums after 1918, as foreign imitations of kanga flooded in (Fair 2001, 76-83). Nevertheless, old wooden blocks still exist in smaller settlements such as Lamu, where printed textiles have been produced until "quite recently" (Mack 1993, 304).

Embroidery also achieved a new prominence, with men, often Islamic scholars, embroidering skullcaps in coastal Swahili towns (Bhacker 1992, 134; Martin 1971, 538-41; Reese 1996, 94). However, these caps, "delicately worked with fine stitching," met severe competition from cheap imports in Dar es Salaam by the 1950s (Leslie 1963, 110).

South Asian immigrants initially dominated workshops making garments (Chauleur 1979, 111; Kilby 1975, 477). Some tailors had a background in textiles, notably Hindus from the Khatri caste of weavers (Enthoven 19202, II, 205; Morris 1968, 139-41). In 1952, five hundred seventy-five tailoring units were counted in Tanganyika, scattered around the territory. There were only forty-seven in 1961, but this reflected changing criteria for statistical purposes (Silver 1984, 44, 90, 94-5, 103).

The first tailoring "factory" in South Africa was recorded in 1907 (Werbeloff 1987, 139). Ashkenazi Jews from Lithuania exploited their skills as tailors and their knowledge of local markets as peddlers to develop a fragmented and small-scale garments industry, employing poor Afrikaner farm girls drifting into cities. They benefited greatly from protectionist South African import tariffs after 1925 (Saron and Hotz 1955, 362-5). They then extended their activities into Central Africa (Cinammon 2004). The Bulawayo Clothing Factory, which appeared in the records in 1920, may have been the pioneer (Wolfgang Döpcke, personal communication). Exports to neighboring territories were noted in 1930 (Mosley 1983, 209). In 1938, seventeen small clothing enterprises represented 3.2 percent of Southern Rhodesia's industrial output by value, and their production reached 17 percent of net imports of textiles and clothing (Mlambo, Pangeti, and Phimister 2000, 25; Southern Rhodesia 1946, 63-5). After 1945, modern industrial 
enterprises came to the fore in finishing South Asian intermediate imports (Kilby 1975, 483).

\subsection{MODERN COLONIAL MILLS}

Modern textile factories faced colonial hesitation rather than outright hostility (Kilby 1975). Metropolitan workers were perhaps those most consistently opposed to "exporting jobs" to the colonies, and they allied with small metropolitan textile entrepreneurs in declining regions, who feared the loss of protected markets. Colonial officials feared the social and political consequences of proletarianization and urbanization. In contrast, competitive Western textile firms were keen to cut costs by producing overseas. Moreover, metropolitan bureaucrats at times backed manufacturing for military reasons, or to appease nationalist leaders, and were increasingly prepared to grant a measure of tariff protection (Clarence-Smith 1985; Drummond 1974; Havinden and Meredith 1993; Marseille 1984).

Large modern integrated textile mills suffered from excessive protection, as well as diseconomies of scale. Skilled labor and capital were exceedingly costly in Africa, and even unskilled factory labor was expensive, as low productivity generally more than offset low wages. A supply of local raw fibers was a mixed blessing, because of poor quality and irregular deliveries. Entrepreneurs were chiefly attracted to the business by cheap land and hydroelectricity, and by high levels of tariff protection. Colonial regimes frowned on diasporic entrepreneurs, notably South Asians, while showering metropolitan firms with protectionist tariffs, quotas, licenses, and monopolies. These were double-edged swords, for any initial spur to investment came at the cost of structural inefficiency, most obviously reflected in a lack of exports beyond the region (Clarence-Smith 1989a; Kilby 1975).

The rising tide of Japanese imports into the Congo Free Trade Zone in the interwar years acted as a precocious spur to the establishment of modern mills (Austen 1987, 136). In 1925, two Belgian textile producers set up the Société Textile Africaine, or Texaf, in Léopoldville (Kinshasa), at the head of the Congo River navigation system into eastern Africa (Heyse 1938, 7-12; Lacroix 1967, 19-20). In 1927, Texaf obtained a concession to generate its own hydroelectric power, setting up a subsidiary for this purpose in 1930 (Heyse 1936, 329-34). This was a state-of-the-art integrated spinning and weaving mill. By 1930, the mill consumed about a fifth of the raw cotton grown in the Congo (Vellut 1985).

The impact of the early 1930s recession on Texaf was severe, but the company survived (Heyse 1938, 7-12). Texaf became a holding company 
in 1934, and the textile business was renamed Société Usines Textiles de Léopoldville, or Utexléo (Heyse 1938, 7-12). An unspecified Belgian bank acquired a controlling stake, and substituted labor for capital. Existing machines were not replaced, and real wages were compressed (Strihou $1961,51-2,62,65,78)$. Output went from 930 tons in 1931 to 1,640 tons in 1940, accounting for about a third of Congolese consumption (Belgium 1949, 576).

The Second World War inaugurated a period of rapid expansion in the Congo. Utexléo took on more workers, and acquired some good spindles and some indifferent secondhand looms in 1942-3. Production rose by 63.4 percent between 1940 and 1945, and the company imported foreign cloth to meet excess demand (Strihou 1961, 52-4). Utexléo's output reached 2,670 tons by 1945 (Belgium 1949, 576). After the war, Utexléo invested more and improved the quality of its finished goods (Strihou 1961, 53-5). Concurrently, Flemish industrialists established FILTISAF in Albertville (Kalemie) in 1946 (Vellut 1985).

The 1925 Belgian initiative sent shock waves through the Portuguese colonies. Although only northern Angola and northern Mozambique lay in the Congo Free Trade Zone, Léopoldville was the hub of a web of water and rail transport links across the continent. Expressing fears that the products of the Congolese factory would invade the Mozambican market, a leading Portuguese entrepreneur requested permission in 1926 to establish a similar industry in Mozambique. However, his plea was rejected (Macedo 1939, 280). Indeed, Antonio Salazar's conservative and authoritarian regime, shaken by the Great Depression, passed a decree in 1932, which guaranteed high fixed prices for colonial raw cotton in Portugal in return for formally prohibiting the creation of textile mills in the colonies (Clarence-Smith 1985, 84-6, 163-5).

Although British East Africa lay entirely within the Congo Free Trade Zone, and the proportion of textile imports from Japan rose to 70 percent during the interwar years, Britain failed to support initiatives to set up local textile mills. It was to no avail that imports had grown beyond a notional threshold for import substitution, and that a free trade area covered Kenya, Uganda, and Tanganyika from 1924. Nicola Swainson blames the Lancashire lobby for this outcome (Swainson 1980, 26-7, 43-5, 124). ${ }^{1}$ In 1937, when an interdepartmental committee examined the question, the Colonial Office poured cold water on arguments for a protected "infant industry." Officials

1 For the general British colonial position, see Havinden and Meredith 1993, 159, 168-74. 
insisted on levying an excise tax on local production that would be equal to tariffs on imports (Drummond 1974, 441-2).

Shortages in the Second World War led to a British reappraisal. A restrictive licensing system, introduced in 1943, applied to cotton yarn, piece goods, and blankets. In 1959, a single textile mill had been authorized for Kenya and Uganda respectively, although several licenses were granted thereafter (International Bank 1962, 275; Swainson 1980, 116-21, 125). By 1963, the combined textile, apparel, and footwear sector employed 3,701 people in Kenya, and a further 3,250 in Uganda (Kilby 1975, 477-8). Uganda's Nyanza Mills, or Nytil, built in Jinja in 1954, integrated spinning, weaving, and finishing. It was built to consume cheap hydroelectricity from the Owen Falls dam, as well as local raw cotton (Elkan 1961, 5-7, 59-60; International Bank 1962, 275; Kilby 1975, 478; Pearson 1969, 125). A textile mill was set up in Thika, Kenya, toward the end of the 1950s, and exported within British East Africa (Mosley 1983, 212, 222; Swainson 1980, 125, 128). In 1952, Tanganyika had two dyeing firms employing eighty people and a cotton-weaving shed with thirty workers. By 1961, there were five weaving mills in the Dar es Salaam area, all small and processing imported yarn (Silver 1984, 74-5, 90-1, 94-5, 102-3. See also Werbeloff 1987, 163-4).

The British generally backed metropolitan capitalists against South Asian rivals, even though the latter had a proven historical track record in manufacturing (Clarence-Smith 1989b). Indians repeatedly asked for permission to manufacture textiles, for which much expertise existed in Gujarat, and the only textile mill in Kenya in the 1950s was a small Indian concern (Swainson 1980, 26-7, 125). Nevertheless, it was Calico Printers of Manchester who developed the large Jinja mill in Uganda. Despite benefiting from a local monopoly and cheap hydroelectricity, the firm lost so much money that the Uganda Development Corporation was obliged to buy the mill in 1957. Astonishingly, Calico Printers was retained as managing agent, turning a profit only because tariff protection was raised to a stiff 30 percent (International Bank 1962, 275; Kilby 1975, 478; Pearson 1969, 125-6). However, in 1963, during the decade of independence, the South Asian firm of Mehta was building a new textile mill, symbolically situated on the opposite bank of the Nile from the Jinja plant (Pearson 1969, 127).

Economic dislocation in the Second World War impelled Salazar to set up textile industries in Angola and Mozambique, mainly owned by metropolitan capitalists (Clarence-Smith 1985, 164-5). In 1950, a large textile factory was nearing completion in central Mozambique (Pitcher 1993, 163-4). Located at Vila Pery (Chimoio), on the railway inland from Beira, it was close to the frontier with Southern Rhodesia (Zimbabwe), and about 
twenty miles from an abundant source of cheap hydroelectric power on the Revue River. The skilled workers were immigrants from Portugal (Spence $1951,83)$. In 1958, this factory consumed 1,774 tons of raw cotton for 14,500 spindles and 460 looms, and in 1960, it employed some 2,000 people. It was reputed to be the largest cotton textile factory in sub-Saharan Africa. In 1954, three textile establishments in Mozambique accounted for more investment than any other economic sector, apart from sugar (Bravo 1963, 82-5; Gersdorff 1958, 66-7). Artur Cupertino de Miranda's Banco Português do Atlântico, founded in 1942 on the basis of the remittance business from Brazil, provided much of the capital for the Sociedade Algodoeira de Fomento Colonial, with textile mills in both Mozambique and Angola. Concession companies, which purchased compulsorily cultivated colonial raw cotton, were junior partners (Clarence-Smith 1985, 169; Pitcher 1993, 163-5).

Some Western entrepreneurs functioned in a more diasporic mode. Roberto Barattolo, an Italian trader in Eritrea before the Second World War, was imprisoned by the British in 1941 and repatriated to Italy. $\mathrm{He}$ returned to Asmara to set up the Cotonoficio Barattolo in 1950. From an initial investment in spinning, he moved to weaving and finishing, and then to clothing, while simultaneously going upstream into raw cotton and ginning. By the time the Ethiopian Derg nationalized the enterprise in 1975, this was perhaps the most fully integrated textile company in eastern Africa. It had grown up gradually and organically, under the watchful eye of an entrepreneur who took a leading position in the resident Italian community. ${ }^{2}$ In contrast, Somalia’s Société de Manufactures Cotonnières Somalies, located in the capital Mogadishu (Muqdisho) and providing about a sixth of internal consumption in 1954, seems to have been owned by an Italian firm (Administration Italienne 1954, 81-2).

Southern African settlers wielded a political power that generally stimulated precocious industrial development, but textiles were an exception. British Central Africa's white miners and farmers opposed protection for consumer goods that might force up the wage rate and thus damage their export prospects. In addition, settler communities were determined to frustrate the economic advance of South Asian communities, most likely to prosper in the textile sector. Furthermore, Lancashire lobbied vigorously against protective tariffs (Brett 1973, 266-81; Mlambo et al. 2000, 12-13). At the imperial Ottawa Conference of 1932, the Southern Rhodesian regime made specific concessions on imports of British cotton piece goods

2 http://www.quirinale.it/elementi/DettaglioOnoroficenze.aspx?decorato=612. 
in return for British guarantees on Southern Rhodesian exports of mineral products (Cole 1968, 29).

The Southern Rhodesian government thus only intervened to encourage the cotton textile industry from 1941, as the war affected supplies. The authorities developed spinning at Gatooma from 1943, with 17,500 spindles installed by 1948 . David Whitehead and Sons, from Lancashire, set up the first large weaving mill in 1951, with production starting two years later. A second spinning mill followed in 1952, with attached weaving and knitting units. The government privatized the Gatooma mill by 1960, seeing public ownership as a temporary aberration (Guillie 1995, 52; Kilby 1975, 483; Mlambo et al. 2000, 31). Exports were stimulated by free trade agreements with South Africa and by the market provided by the Federation of Central Africa from 1953 to 1963 (Mlambo et al. 2000, 37-8, 42-5; Mosley $1983,212,218-19)$. The textile and garments industries grew at an average annual rate of 20.8 percent from 1946 to 1953 . By 1957-8, spinning and weaving employed 6,574 people in twenty-six establishments. Up to a third of Southern Rhodesia's textile output was destined for South Africa in the 1950s (Mlambo et al. 2000, 31, 45-7). By 1964, exports of textiles were worth roughly half as much as imports (Mosley 1983, 218-19).

Although South Africa industrialized early and extensively, textiles were not the leading sector. Secondary industries were a preserve for employing poor whites, but they were particularly costly to employ in textiles (Cronje 1952, 24-5; Saron and Hotz 1955, 364-5). A Cape blanket factory was founded in 1891, and woolen and cotton blankets were the country's only significant textile products for a long time. In 1933-4, there were twelve textile establishments employing 2,358 workers. Once again, the real boom came during and after the Second World War, with high levels of tariff protection, so that by around 1960 there were 104 factories and 29,142 workers (Beinart 1982, 24-5; Cronje 1952, 24; Du Toit 1978, 33, 37-8, 43). In 1967, 71,000 employees were recorded (Chauleur 1979, 113).

Fickle metropolitan capital came to the fore in this late spurt in South Africa. Textile firms from Britain, France, and Italy lacked electricity and other inputs at home to meet shortages due to the war in 1945, and relocated to South Africa. The low productivity of African labor was a disincentive, however, and investment fell drastically after 1951, as postwar global shortages turned to glut (Cronje 1952, 26-7; Kilby 1975, 483). Local Jewish concerns in the garments business, moving upstream to produce cloth, showed a more long-term commitment to the industry (Saron and Hotz 1955, 362-4). 


\subsection{THE ARTICULATION OF MODERN COLONIAL FACTORY PRODUCTION WITH ARTISANS}

Modern textile factories in eastern Africa displayed little or no synergy with small producers (Pearson 1969, 124). Both Western and settler industrialists were unaccustomed to working with artisans. Indeed, many managers, isolated in their gleaming new factories and cosseted by officials, seem not to have realized that there were textile artisans at all. Discrimination on grounds of culture and race and weak or nonexistent representative institutions made it all the more difficult to bridge the cultural gap. The strongest linkages were in South Africa, where Jewish garment entrepreneurs and workers were legally deemed white.

Overall, entrepreneurs in Africa deliberately turned their backs on artisans, seeking out isolated hydroelectric sites where they could obtain cheap power and control the entire production process from start to finish. In particular, factories rarely supplied yarn to weavers, in stark contrast to the situation in Asia. Tellingly, the International Bank for Reconstruction and Development strongly criticized the Jinja mill in Uganda for not selling yarn or plain cloth within the colony. British managers seem to have feared competition from those who might purchase semi-manufactures from their mill (International Bank 1962, 275). That said, Utexléo's output of yarn rose twice as fast as that of cloth in the 1950s, suggesting that this Congolese enterprise may have been selling yarn to artisans (Strihou 1961, 55).

Clothing workshops had somewhat more positive links with modern mills, for integrated factories rarely extended to producing garments. Small workshops, making items of clothing mainly for the African market, thus purchased cloth locally (Döpcke 1992, 104-5; Mlambo et al. 2000, 25; Wilde 1971, II, 7, 3-4).

\subsection{THE IMPACT OF INDEPENDENCE ON MODERN MILLS}

Independence from around 1960 was accompanied by policies of import substitution, which were particularly ill suited to small extroverted economies (Chauleur 1979; Werbeloff 1987). Allied policies of modernization and state ownership made matters worse. Inefficient and corrupt independent governments interfered incessantly, whether they owned or regulated mills. Far from encouraging diasporic entrepreneurs, they sought to reduce their share of manufacturing (Morris 1968, 145). 
From the 1960s to the 1980s, the general trend was thus for states to encourage large, integrated, and highly protected textile mills to meet the demands of restricted national markets. Thought was rarely given to exporting competitively within regions, let alone on the world market. Such factories seemed to be quite successful for a while, but only at the cost of ramping up protectionist tariffs, which already stood at an effective average of 269 percent for textiles in Tanzania in 1966. Foreign exchange shortages then throttled imports of inputs, fuel, and spare parts. Power shortages multiplied, labor discipline collapsed, maintenance ceased, productivity plummeted, location of new plants obeyed political criteria, debts ballooned, capacity utilization fell, and smuggled imports of foreign textiles soared. Private mills did better than state-owned ones, but only marginally (Chauleur 1979, 103-10, 109-13; Valk 1996, 146-52, 216-42; Werbeloff 1987).

As the "white elephants" of modernization theory and Marxism became increasingly discredited, export markets for textiles were created by multifiber agreements from 1973, and international agencies pushed strongly for export substitution on Asian lines from the 1980s. However, international agreements provided highly artificial stimuli, liable to sudden and devastating changes as international politics shifted. Foot-loose international entrepreneurs were then all too quick to move on to new pastures (Valk 1996, 107-10, 128, 137). The ending of the World Trade Organization's textile and clothing quota system in 2005 was a particularly heavy blow for Africa (Maliti 2005).

An alternative, albeit weak, reaction to the disastrous policies adopted at independence was to foster neglected and long-suffering textile artisans. This policy shift was aided by a glorification of precolonial "authenticity." However, this all too easily degenerated into folklore, which was desultorily marketed to sparse foreign tourists (Guillie 1995, 51; Polakoff 1982, 4-10).

After the Derg toppled Haile Selassie in Ethiopia in 1974, the "commanding heights" of the textile industry, at that time the third largest in subSaharan Africa, passed into the hands of the state-owned National Textile Corporation. In 1982, this body controlled twenty-one mills and employed some twenty-nine thousand people. Only some thirty small-scale knitting workshops and two small spinning and weaving enterprises fell outside the state's net. The sector suffered from poor and uneven productivity. Some two-thirds of total output came from the Diredawa mill, an old mill founded in 1943, but which was efficiently managed by a Japanese enterprise (Werbeloff 1987, 93-5). 
A tale of two mills in Tanzania similarly indicates how state-owned textile plant could come in very different forms. Following the Arusha Declaration's call for economic self-sufficiency in 1967, the government set up two factories. Mwanza Textiles, only partially state owned, installed the most modern automated machinery that the West had to offer, at immense cost. The factory proceeded to lose money by the bucketful. In contrast, Friendship Mill, entirely state owned, was equipped with antiquated secondhand Chinese machinery, some of which had been designed in the 1930s. Employing far more workers, and thus soaking up urban unemployment, it was quite consistently profitable. Indeed, the Friendship Mill at times outperformed privately managed mills (James 1995, 35-6).

International sanctions constrained settler-ruled South Africa and Southern Rhodesia (Zimbabwe), but they obtained capital from Israel and Taiwan, and exported some of their output. By the mid-1980s, the Frame Group was South Africa's eighth largest company in terms of share capital, employed some twenty-two thousand people, and was allegedly the largest producer of blankets in the world. Not only did it spin, weave, and finish cloth, but it also produced garments, which was quite a common pattern in South Africa. The Tongaat Group, the country's second largest textile producer, even integrated upstream into cotton ginning (Werbeloff 1987, 140-2, 180). In contrast, Zimbabwe's textile sector declined rapidly after real independence had been achieved in 1980 (Valk 1996, 142-4; Werbeloff 1987, 181-2). Cone Textiles, the largest employer, went into liquidation in 1995, and David Whitehead, a Lonrho subsidiary, struggled to survive (Guillie 1995, 52).

The factory sector turned to copying imported finished cloth specially made for the African market, with Malagasy factories turning out brightly colored kanga with proverbs in Malagasy (Fee 2002, 69). Producers in Kenya, notably the integrated Rift Valley Textiles (Rivatex) of Eldoret, initially succeeded in ousting foreign kanga (Hilger 1995, 44). The same was true in Tanzania, but prices then rose above those of imports (Zawawi 2005, 29). Maurer Textiles of Switzerland managed Sotexki in Kisangani, in the eastern Congo, producing chitenge (kitenge), but political uncertainty and Asian copies undermined the enterprise (Guillie 1995, 51). Zambian factories developed "imiwax" in the 1970s to replace foreign copies of wax-dyed batik from Southeast Asia. However, by the 1990s, Mulungushi Textiles was under such pressure from imports that it switched to exporting undyed yarn and grey cloth (Guillie 1995, 51-2). 
Imports of cheap, or even free, secondhand clothes from the West became a new and major threat to textile output in eastern Africa from the 1980s, although such imports were generally underreported or even unreported (Valk 1996, 116, note 25, 216). They undercut most kinds of local business, even if T-shirts, printed with topical local material, were able to compete (Guillie 1995, 52; Hilger 1995, 45). Zambian enterprises, unable to compete, sold their sewing machines for a song and witnessed the erosion of skills (Matheson 2000).

The alternative strategy promoted by multilateral organizations, namely export-substituting industrialization, remains to prove its worth. Italy's Zambaiti Group, an old textile company, bought Asmara's Cotonoficio Barattolo for the symbolic sum of one dollar in 2004. With experience of producing in China, the firm invested E13 million to revive the company. Integrated from spinning to clothing, Zambaiti Eritrea (Zaer) has 85 percent of its output earmarked for export. ${ }^{3}$

However, the experience of Mauritius casts a shadow on this strategy. The small island country experimented with Export Processing Zones from 1970, in order to lessen dependence on sugar. Liberal tax, customs, capital transfer, and labor regulations attracted foreign textile companies. They also obtained cheap water, electricity, and rents, as well as guarantees against nationalization. The policy was intensified from 1982, leading to a boom in the production of cloth and garments for export to the West, with about one hundred thousand workers employed by the mid-1990s. Unfortunately, this artificially generated sector could not stand up to growing Asian competition and global trade liberalization, and was in a serious crisis by 2003, which shows no signs of abating (Neveling 2010, 76-82; Valk 1996, 138-41).

\subsection{THE PERSISTENCE OF ARTISANAL TEXTILES IN THE ERA OF INDEPENDENCE}

Despite this official love-in with large integrated modern textile mills, the neglected and even despised artisans of eastern Africa survived (Valk 1996, 165). They also had to overcome major new hurdles, such as shortages of imported yarn, due to protectionism and foreign exchange crises, and outages in electricity supply (Renne 1995, 146). South Asian preponderance in tailoring, for example in Uganda, engendered additional official hostility (Wilde 1971, XII, 2, 6).

3 http://www.eritreaeritrea.com/zambaiti_eritrea_plc.htm. 
The Horn of Africa retained the healthiest artisanal sector. Ethiopia's weavers kept producing through the Marxist rule of the Derg after 1974, although makers of garments were forced into ineffective cooperatives (Werbeloff 1987, 94, 96). By the 1990s, weaving was in full swing again, with traditional double-heddle pit looms. Indeed, Ethiopia was declared an exception to the overall decline of artisanal textiles in eastern Africa (Gillow 2003, 157-60, 164).

Sudan was unusual in formally acknowledging the existence of an artisanal textile sector after independence in 1956. In addition to a program of modern mills, the government initiated weaving sheds containing up to 100 looms. In 1970, it was estimated that "handicraft producers" met about half the domestic demand for textiles, and the sector remained dynamic in the 1990s (Valk 1996, 103; Werbeloff 1987, 156). Tailoring was of further importance, often in the hands of West African immigrants (Yamba 1995, $98-9,112,140)$.

Tanzania's brand of humanistic socialism favored artisans, at least on paper. The National Small Industries Corporation was set up in 1967, providing subsidized rents for tailoring and other workshops, albeit with poor facilities and a reluctance to eject defaulting tenants (Wilde 1971, X, 3-7). By the 1980s, there was a conscious policy, largely borrowed from India, of developing small-scale textile manufacturing. On the one hand, there was to be a "decentralized" sector, typically consisting of "semi-urban" units, with knitting machines and ten to forty semiautomatic looms. On the other hand, there was to be a "manual" sector in rural areas. Three "handloom manufacturing units" were charged with distributing looms, of an unspecified type. Tanzania preached this model to fellow members of SADCC, but with indifferent success (Werbeloff 1987, 164, 166). Although it is unclear how these policies panned out on the ground, Gillow seems excessively pessimistic in asserting that handloom weaving has become merely a matter of "historical interest" (Gillow 2003, 158).

After an initial stress on modernization, Madagascar tipped the balance back toward supporting ancient traditions from 1992. Handweaving was concentrated in specialized quarters, small towns, and villages, especially in the highlands and the south. Weavers exported their wares to other parts of the island through middlemen, while regular fashion shows and sales to tourists helped to gain markets in the West. Output ranged from resurrected noble cloths to cheap loose weaves, the latter competing with imports to meet the needs of poor households. Men wove more often, at least in the capital city, breaking with the ancient gender division of labor. Tailors also worked to express ethnic identities in cloth. However, attempts 
to use handweaving to relieve extreme rural poverty failed, as did cooperatives, for some capital was needed for weaving, and fiercely independent households had little desire to cooperate (Fee 2002, 67-70, 74-86. See also Peers 1995, 46-7).

The revival of artisanal efforts in Madagascar was accompanied by technical adaptations, even if Valk criticized "outdated technologies" (Valk 1996, 100). Double-heddle treadle looms still existed in the northeast in the 1980s, and there were efforts to spread the technique, build larger looms, and introduce "European looms" (Fee 2002, 78; Gillow 2003, 214; Mack 1989, 31-2; Peers 1995, 47). The most expensive cloths were made with hand-spun yarn on old ground looms, and were colored with natural dyes. There were experiments with new natural fibers, for example a sisal warp. However, most artisans employed chemical dyes and factory-made yarn, including shiny imported synthetic fibers for cheaper wares (Fee 2002, 74-9, 85-6).

Davison and Harries consider that weaving and spinning skills were "almost forgotten" by the 1950s in southeastern Africa, although their own fascinating evidence clearly does not support this pessimistic conclusion. Thus, Shona and Chewa weavers of the 1970s, in Zimbabwe and Malawi respectively, wove belts for ritual purposes, such as spirit possession cults (Davison and Harries 1980, 175, 181, 185, 187-91). Similarly, weavers in Barue were producing machira as late as the 1970s (Davison and Harries 1980, 181-2; Lobato 1957, 242). As Africans gradually moved into textiles in South Africa, they embellished machine-made cloth with Ndebele and Zulu beadwork (Guillie 1995, 54).

\subsection{CONCLUSION}

Textiles formed a sector of modest dimensions in eastern Africa, and yet production persisted throughout the early modern and modern periods. Handicraft techniques progressed and proto-industrial structures emerged, although far too little research has been carried out on the artisanal sector. Modern mills appeared in the twentieth century, but were generally too capital-intensive, overly protected, and poorly articulated with artisanal production. That said, the mills of well-rooted diasporas, notably South Asian and Jewish, fared better than those of Western capitalists, white settlers, or independent governments.

This story gives the lie to extreme theories of underdevelopment, in which Africa was reduced to a source of raw materials and a captive 
market for foreign manufactures. In reality, South Asian textiles failed to deindustrialize early modern eastern Africa, probably because of rising African productivity. The model proposed here is that merchants reduced costs and uncertainties and spread best technical practice. Western and Asian textile industries more strongly affected the region from the late nineteenth century, but again without fulfilling Dependentista predictions. The existing artisanal sector did not die, not even hand spinning, and new workshops sprang up producing garments with sewing machines.

That said, the consequences of creating a disarticulated cotton textile sector were negative. Large mills had few or no moorings in civil society and were incapable of stimulating artisanal production. Once colonial or settler rule ended, such enterprises either lost the crutches of state support or became "white elephants," draining resources from the wider economy. This was an important factor holding back the emergence of "African tigers." Indeed, the bitter irony of independence has been that nationalists have been passionate about achieving industrialization, and yet have systematically killed the geese that laid the industrial eggs. For the historian, however, the era since independence is little more than the blink of an eyelid. The resilience of eastern Africa's artisanal textile sector in the past is a good augury for its prosperity in the future, and it should certainly act as a spur for better studying its history.

\section{References}

Administration Italienne de Tutelle de la Somalie. (1954). Plans de développement économique de la Somalie, années 1954-1960. Rome: Istituto Poligrafico dello Stato.

Alpers, Edward A. (1975). Ivory and Slaves in East Central Africa. London: Heinemann. (1983). "Futa Benaadir: Continuity and Change in the Traditional Cotton Textile Industry of Southern Somalia, c.1840-1980." In Entreprises et Entrepreneurs en Afrique, XIXe et XXe siècles I: 77-98. Paris: L'Harmattan.

Antunes, Luis Frederico Dias. (1992). “A Actividade da Companhia de Comercio Baneanes de Diu em Moçambique, 1688-1777," MA Thesis, Universidade Nova de Lisboa.

Austen, Ralph. (1987). African Economic History, Internal Development and External Dependency. London: James Currey.

Baldry, John. (1982). Textiles in Yemen: Historical References to Trade and Commerce in Textiles in Yemen, from Antiquity fo Modern Times. London: British Museum.

Bates, Darrell. (1979). The Abyssinian Difficulty: The Emperor Theodorus and the Magdala Campaign, 1867-68. Oxford: Oxford University Press. 
Beinart, William. (1982). The Political Economy of Pondoland, 1860-1930. Cambridge: Cambridge University Press.

Belgium (1949). Ministère des Colonies, Plan Décennal Pour Le Développement Économique et Social du Congo Belge, Brussels: De Visscher.

Bhacker, M. Reda. (1992). Trade and Empire in Muscat and Zanzibar: Roots of British Domination. London: Routledge.

Bhila, H. H. K. (1982). Trade and Politics in a Shona Kingdom: The Manyika and Their African and Portuguese Neighbours, 1575-1902. London: Longman.

Bravo, Nelson Saraiva. (1963). A Cultura Algodoeira Na Economia do Norte de Moçambique. Lisbon: Junta de Investigações do Ultramar.

Brett, E. A. (1973). Colonialism and Underdevelopment in East Africa, 1919-1939. London: Heinemann.

Bronson, Bennet. (2004). "Wrapping Up Malagasy Textiles." In Unwrapping the Textile Traditions of Madagascar, edited by Chapurukha M. Kusimba, J. Claire Odland, and Bennet Bronson, 164-9. Los Angeles, CA: Fowler Museum.

Burton, R. F. (1860). The Lake Regions of Central Africa. London: Longman, Green, Longman, and Roberts.

(1894). First Footsteps in East Africa or an Exploration of Harar. London: Tylston and Edwards, 2nd ed.

Campbell, Gwyn. (2005). An Economic History of Imperial Madagascar, 1750-1895: The Rise and Fall of an Island Empire. Cambridge: Cambridge University Press.

Cassanelli, Lee V. (1988). "The Ending of Slavery in Italian Somalia: Liberty and the Control of Labor, 1890-1935." In The End of Slavery in Africa, edited by Suzanne Miers and Richard Roberts, 308-31. Madison: University of Wisconsin Press.

Cattelani, G. (1897). Lavvenire Coloniale D'Italia Nel Benadir. Naples: F. Giannini e Figli.

Chauleur, Pierre. (1979). L'Afrique Industrielle. Paris: G. P. Maisonneuve et Larose.

Chiesi, Gustavo. (1909). La Colonizzazione Europea Nell' Est Africa: Italia, Inghilterra, Germania. Turin: Unione Tipografico-Editrice Torinese.

Cinnaman. John. (2004). “The Jews of Manicaland," http://www.zjc.org.il/showpage .php?pageid=155.

Clarence-Smith, William G. (1985). The Third Portuguese Empire, 1825-1975: A Study in Economic Imperialism. Manchester: Manchester University Press.

(1989a). "The Effects of the Great Depression of the 1930s on Industrialisation in Equatorial and Central Africa." In The Economies of Africa and Asia in the InterWar Depression, edited by Ian Brown, 170-202. London: Routledge.

(1989b). "Indian Business Communities in the Western Indian Ocean in the Nineteenth Century." The Indian Ocean Review, 2(4): 18-21.

(2004). "Middle Eastern Migrants in the Philippines: Entrepreneurs and Cultural Brokers." Asian Journal of Social Science, 32(3): 425-57.

(2006). Islam and the Abolition of Slavery. London: Hurst \& Co.

(2009). "The Production of Cotton Textiles in Early Modern South-East Asia." In The Spinning World: A Global History of Cotton Textiles, 1200-1850, edited by Giorgio Riello and Prasannan Parthasarathi, 127-42. Oxford: Oxford University Press.

(2011). "The Expansion of Cotton Textile Production in the Western Indian Ocean, c1500-c1850." In Indian Ocean Worlds: Essays in Honour of Prof. K. N. Chaudhuri, 
edited by Stefan Halikowski-Smith, 84-106. Newcastle-upon-Tyne: Cambridge Scholars Publishing Ltd.

Cole, R. L. (1968). “The Tariff Policy of Rhodesia, 1899-1963.” Rhodesian Journal of Economics, 2(2): 28-47.

Coquet, Michèle. (1993). Textiles Africains. Paris: Adam Biro.

Cronje, F. J. C. (1952). "The Textile Industry in the Union of South Africa." South African Journal of Economics, 20(1): 23-30.

Cuypers. Jan-B. (2004). L'habillement du Rwanda Ancient. Tervuren: Musée Royal de l'Afrique Centrale.

Darish, Patricia. (1989). "Dressing for the Next Life: Raffia Textile Production and Use among the Kuba of Zaïre." In Cloth and Human Experience, edited by Annette B. Weiner and Jane Schneider, 117-40. Washington, DC: Smithsonian Institution Press.

Darkwah, R. H. Kofi. (1975). Shewa, Menelik, and the Ethiopian Empire, 1813-1889. London: Heinemann.

Davison, Patricia and Patrick Harries. (1980). "Cotton Weaving in South-East Africa: Its History and Technology." Textile History, 11: 175-92.

Deschamps, Hubert. (1947). Madagascar. Paris: Berger Levrault.

Döpcke, Wolfgang. (1992). Das Koloniale Zimbabwe in der Krise; Eeine Wirtschafts- und Sozialgeschichte, 1929-1939. Hamburg: Lit.

Drummond, Ian. (1974). Imperial Economic Policy, 1917-1939: Studies in Expansion and Protection. London: George Allen and Unwin Ltd.

Du Toit, Bettie. (1978). Ukubamba Amadolo: Workers' Struggles in the South African Textile Industry. London: Onyx Press.

Edgerton, David. (2008). The Shock of the Old: Technology and Global History since 1900. London: Profile.

Elkan, Walter. (1961). The Economic Development of Uganda. London: Oxford University Press.

Ellis, William. (1838). History of Madagascar. London: Fisher, Son \& Co.

Enthoven, Reginald E. (1920-2). The Tribes and Castes of Bombay. Bombay: Government Central Press.

Ewald, Janet. (1990). Soldiers, Traders and Slaves: State Formation and Economic Transformation in the Greater Nile Valley, 1700-1885. Madison: University of Wisconsin Press.

Fair, Laura J. (2001). Pastimes and Politics: Culture, Community and Identity in PostAbolition Urban Zanzibar, 1890-1945. Oxford: James Currey.

Fee, Sarah. (2002). "Madagascar's Textiles through History." In Objects as Envoys: Cloth, Imagery and Diplomacy in Madagascar, edited by Christine M. Kreamer and Sarah Fee, 33-93. Washington, DC: Smithsonian Institution.

(2005). “Ze Mañe Aze: Looking for Patterns in Malagasy Cloth.” In Textiles in Indian Ocean Societies, edited by Ruth Barnes, 85-109. London: RoutledgeCurzon.

Gersdorff, Ralph von. (1958). Moçambique. Bonn: Kurt Schroeder.

Gibb, H. A. R. (1962). The Travels of Ibn Battuta, A.D. 1325-1354, Volume 2. Cambridge: Cambridge University Press.

Gillow, John. (2003). African Textiles: Colour and Creativity across a Continent. London: Thames and Hudson. 
Godley, Andrew. (2001). “The Global Diffusion of the Sewing Machine, 1850-1914." Research in Economic History, 20: 1-45.

Grandidier, Alfred and Guillaume Grandidier. (1928). Histoire Physique, Naturelle et Politique de Madagascar, volume IV, Ethnographie de Madagascar, Tome quatrième. Paris: Hachette.

Great Britain. (1896). "Statement of the Trade of British India with British Possessions and Foreign Countries for the Five Years 1890-1 to 1894-5." Parliamentary Papers, 1896, Accounts and Papers, C. 7997.

Great Britain, Foreign Office. (1920). Anglo-Egyptian Sudan. London: HMSO.

Guillain, Ch. (1856-7) Documents sur L'histoire, La Géographie et Le Commerce de l'Afrique Orientale. Paris: A. Bertrand.

Guillie, Jackie. (1995). "Southern African Textiles Today: Design, Industry, and Collective Enterprise." In The Art of African Textiles: Technology, Tradition, and Lurex, edited by John Picton, 51-4. London: Barbican Art Gallery.

Havinden, Michael and David Meredith. (1993). Colonialism and Development: Britain and Its Tropical Colonies, 1850-1960. London: Routledge.

Hecht, Ann. (1989). The Art of the Loom: Weaving, Spinning and Dyeing across the World. London: British Museum Publications.

Heyse, T. (1936). "Cessions et Concessions Foncières du Congo." Congo, 2: 329-38.

(1938). "Cessions et Concessions Foncières du Congo." Congo, 1: 7-12.

Hilger, Julia. (1995). “The Kanga: An Example of East African Textile Design.” In The Art of African Textiles: Technology, Tradition, and Lurex, edited by John Picton, 44-5. London: Barbican Art Gallery.

Horton, Mark. (1996). Shanga: The Archaeology of a Muslim Trading Community on the Coast of East Africa. London: British Institute in Eastern Africa.

International Bank for Reconstruction and Development. (1962). The Economic Development of Uganda. Baltimore, MD: Johns Hopkins University Press.

Isaacman, Allen. (1972). Mozambique: The Africanisation of a European Institution: The Zambezi Prazos 1750-1902. Madison: University of Wisconsin Press.

Issawi, Charles. (1966). The Economic History of The Middle East, 1800-1914: A Book of Readings. Chicago: University of Chicago Press.

James, Jeffrey. (1995). The State, Technology and Industrialization in Africa. New York: St. Martin's Press.

Jeater, Diana. (2007). Law, Language and Science: The Invention of the "Native Mind" in Southern Rhodesia, 1890-1930. Portsmouth, NH: Heinemann.

Johnson, Marion. (1978). “Technology, Competition and African Crafts." In The Imperial Impact: Studies in the Economic History of Africa and India, edited by Clive Dewey and A. G. Hopkins, 259-69. London: Athlone Press.

Kent, Raymond K. (1970). Early Kingdoms in Madagascar, 1500-1700. New York: Holt, Rinehart and Wilson.

Kilby, Peter. (1975). "Manufacturing in Colonial Africa." In Colonialism in Africa, Volume 4, The Economics of Colonialism, edited by Peter Duignan and L. H. Gann, 470-520. Cambridge: Cambridge University Press.

Kjekshus, Helge. (1977). Ecology, Control and Economic Development in East African History: The Case of Tanganyika 1850-1950. Berkeley: University of California Press. 
Kuhn, Dieter. (1988). Science and Civilisation in China, Volume 5, Part IX: Textile Technology: Spinning and Reeling. Cambridge: Cambridge University Press (section 31).

Kusimba, Chapurukha M. J., Claire Odland, and Bennet Bronson, Eds. (2004). Unwrapping the Textile Traditions of Madagascar. Los Angeles, CA: Fowler Museum.

Lacroix, Jean-Louis. (1967). Industrialisation au Congo: La Transformation des Structures Économiques. Paris: Mouton.

Lamb, Venice. (2005). Looms Past and Present: Around the Mediterranean and Elsewhere. Hertingfordbury: Roxford Books.

Landen, Robert G. (1967). Oman since 1856. Princeton, NJ: Princeton University Press.

Larson, Pier. (2000). Becoming Merina in Highland Madagascar: History and Memory in the Age of Enslavement. Oxford: James Currey.

Leslie, J. A. K. (1963). A Survey of Dar es Salaam. London: Oxford University Press.

Levine, Donald L. (1974). Greater Ethiopia: The Evolution of a Multiethnic Society. Chicago: Chicago University Press.

Lewis, Herbert S. (2001). Jimma Abba Jifar: An Oromo Monarchy, Ethiopia, 1830-1932. Lawrenceville, NJ: The Red Sea Press, 2nd ed.

Lobato, Alexandre. (1957). Evolução Administrativa e Económica de Moçambique, 17521763. Lisbon: Agência Geral Ultramarina.

Macedo, Alberto Cardoso Martins de. (1939). "Relações Entre a Indústria Nacional e a Agricultura Colonial.” Boletim da Sociedade de Geografia de Lisboa, 57: 267-90.

Machado, Pedro. (2005). "Gujarati Indian Merchant Networks in Mozambique, 1777-c. 1830." PhD Thesis, University of London.

(2009). "Awash in a Sea of Cloth: Gujarat, Africa and the Western Indian Ocean, 1300-1800." In The Spinning World: A Global History of Cotton Textiles, 1200-1850, edited by Giorgio Riello and Prasannan Parthasarathi, 161-79. Oxford: Oxford University Press.

Mack, John. (1987). "Weaving, Women and the Ancestors in Madagascar." Indonesia Circle, 42: 76-91.

(1989). Malagasy Textiles. London: Shire Publications.

(1993). "Sub-Saharan Africa and the Offshore Islands." In 5000 Years of Textiles, edited by Jennifer Harris, 295-305. London: British Museum Press.

Maliti, Tom. (2005). "Rise and Fall of African Textile Industry Provides Cautionary Tale.” http://www.busrep.co.za/general/print_article.php?fArticleId+2447442\&Se ctionId+552\&fSetId=662 (consulted July 5, 2010).

Marseille, Jacques. (1984). Empire Colonial et Capitalisme Français, Histoire d'un Divorce. Paris: Albin Michel.

Martin, Bradford G. (1971). "Notes On Some Members of the Learned Classes of Zanzibar and East Africa in the Nineteenth Century." African Historical Studies, 4 (3) 525-45.

Matheson, Ishbel. (2000). “Charity Killing Zambia’s Textile Industry.” BBC News Online. December 25.

Mlambo, A. S., E. S. Pangeti, and Ian Phimister. (2000). Zimbabwe, a History of Manufacturing, 1890-1995. Harare: University of Zimbabwe Publications.

Morris, H. S. (1968). The Indians in Uganda. London: Weidenfeld and Nicolson. 
Mosley, Paul. (1983). The Settler Economies: Studies in the Economic History of Kenya and Southern Rhodesia, 1900-1963. Cambridge: Cambridge University Press.

Mudenge, Stanley I. G. (1988). A Political History of Munhunmutapa, c. 1400 to 1902. Harare: Zimbabwe Publishing House.

Munro, J. Forbes. (1984). Britain in Tropical Africa, 1880-1960, Economic Relationships and Impact. London: Macmillan.

Neveling, Patrick. (2010). "Von Nutzen der Geschichte, vom Wissen der Akteure und vom Nachteil der Multi-Sited Ethnography: Welthandel, Wirtschaftskrise und Standortwettbewerb in Mauritius Anfang des 21. Jahrhunderts." Sociologus: Zeitschrift für empirische Ethnosociologie und Ethnopsychologie, 60(1): 71-97.

Newitt, Malyn. (1987). "East Africa and Indian Ocean Trade." In India and the Indian Ocean, 1500-1800, edited by Ashin Das Gupta and M. N. Pearson, 201-33. Calcutta: Oxford University Press.

(1995). A History of Mozambique. London: Hurst.

(2002). East Africa: Portuguese Encounters in the World in the Age of Discoveries. Aldershot: Ashgate.

Palat, Ravi A. and Immanuel Wallerstein. (1999). "Of What World-System Was Pre1500 'India' A Part?” In Merchants, Companies and Trade: Europe and Asia in the Early Modern Era, edited by Sushil Chaudhury and Michel Morineau, 21-41. Cambridge: Cambridge University Press.

Pankhurst, Richard. (1968). Economic History of Ethiopia, 1800-1935. Addis Ababa: Haile Selassie I University Press.

Parthasarathi, Prasannan. (2011). Why Europe Grew Rich and Asia Did Not: Global Economic Divergence, 1600-1850. Cambridge: Cambridge University Press.

Pearson, D. S. (1969). Industrial Development in East Africa. Nairobi: Oxford University Press.

Pearson, M. N. (1998). Port Cities and Intruders: The Swahili Coast, India and Portugal in the Early Modern Era. Baltimore, MD: Johns Hopkins University Press.

Peers, Simon. (1995). "Weaving in Madagascar." In The Art of African Textiles: Technology, Tradition, and Lurex, edited by John Picton, 46-7. London: Barbican Art Gallery.

(2004). "History and Change in the Weaving of Highland Madagascar." In Unwrapping the Textile Traditions of Madagascar, edited by Chapurukha M. Kusimba, J. Claire Odland, and Bennet Bronson, 142-53. Los Angeles, CA: Fowler Museum.

Picton, John and John Mack. (1989). African Textiles. London: British Museum, 2nd ed.

Pirio, Gregory R. (1982). "Commerce, Industry and Empire: The Making of Modern Portuguese Colonialism in Angola and Mozambique, 1890-1914." PhD Thesis, University of California at Los Angeles.

Pitcher, M. Anne. (1993). Politics in the Portuguese Empire: The State, Industry and Cotton, 1926-1974. Oxford: Clarendon Press.

Polakoff, Claire. (1982). African Textiles and Dyeing Techniques. London: Routledge and Kegan Paul.

Prestholdt, Jeremy G. (1998). As Artistry Permits and Custom May Ordain: The Social Fabric of Material Consumption in the Swahili World, circa 1450 to 1600. Evanston, IL: Northwestern University, PAS Working Paper No. 3. 
Reese, Scott S. (1996). "Patricians of the Benaadir; Islamic Learning, Commerce, and Somali Urban Identity in the Nineteenth Century." PhD Thesis, University of Pennsylvania.

Renne, Elisha P. (1995). Cloth That Does Not Die: The Meaning of Cloth in Bùnú Social Life. Seattle: University of Washington Press.

Rita-Ferreira, António. (1999). African Kingdoms and Alien Settlement in Central Mozambique, c. Fifteenth to Seventeenth Century. Coimbra: Universidade de Coimbra.

Robecchi-Bricchetti, Luigi. (1899). Somalia e Benadir; Viaggio de Esplorazione Nell'Africa Orientale. Milan: Carlo Aliprandi.

Roberts, Edmund. (1972). Embassy to the Eastern Courts of Cochin-China, Siam and Muscat in the US Sloop-of-War Peacock, during the Years 1832-3-4. Wilmington, DE: Scholarly Resources Ltd., reprint of $1837 \mathrm{ed}$.

Roth, H. Ling. (1977). Studies in Primitive Looms. Bedford: Ruth Bean, 4th ed.

Saron, Gustav and Louis Hotz. (1955). The Jews in South Africa: A History. London: Oxford University Press.

Schaedler, Karl-Ferdinand. (1987). Weaving in Africa South of the Sahara. Munich: Panterra.

Silver, M. S. (1984). The Growth of Manufacturing Industry in Tanzania: An Economic History. Boulder, CO: Westview Press.

Simoons, Frederick J. (1960). Northwest Ethiopia: Peoples and Economy. Madison: University of Wisconsin Press.

Southern Rhodesia. (1946). Report of the Committee of Enquiry into the Protection of Secondary Industries in Southern Rhodesia. Salisbury: Government Printer (also known as the "Margolis Report").

Spence, C. F. (1951). The Portuguese Colony of Mozambique: An Economic Survey. Cape Town: A. A. Balkema.

Stefanini, Giuseppe. (1922). In Somalia: Note e Impressioni di Viaggio. Florence: Le Monnier.

Swainson, Nicola. (1980). The Development of Corporate Capitalism in Kenya, 19181971. London: Heinemann.

Strihou, Jacques van Ypersele de. (1961). "Variations des Coefficients de Fabrication dans Une Entreprise Congolaise, et Équilibre économique, 1931-1958." Bulletin de l'Institut de Recherches Économiques de Louvain, 27 (2): 47-96.

Valk, Peter de. (1996). African Industry in Decline: The Case of Textiles in Tanzania in the 1980s. Basingstoke: Macmillan.

Vandewalle, G. (1966). De Conjuncturele Evolutie in Kongo en Ruanda-Urundi, van 1920 tot 1939, en van 1949 tot 1958. Gent: Rijksuniversiteit te Gent.

Vansina, Jan. (1998). "Raffia Cloth in West Central Africa, 1500-1800." In Textiles: Production, Trade and Demand, edited by Maureen Fennell Mazzaoui, 263-81. Aldershot: Ashgate.

Vellut, Jean-Luc. (1985). “Originalités et Limites de L'industrie Manufacturière au Congo Belge, c.1920-1960." Unpublished longer version of a piece published under this title in Les Belges à Létranger: 150 Ans de Réalisations dans Le Tiers-monde, catalogue for an exhibition held in Brussels March 21 to April 24. 
Werbeloff, Arnold. (1987). Textiles in Africa: A Trade and Investment Guide. London: Alain Charles.

Wilde, John C. de. (1971). The Development of African Private Enterprise. Washington, DC: International Bank for Reconstruction and Development.

Wingate, F. R. (1986). Ten Years' Captivity in the Mahdi's Camp, 1882-1892, from the original manuscript of Father Joseph Ohrwalder. London: Darf, 2nd ed.

Wylde, Augustus B. (1901). Modern Abyssinia. London: Methuen.

Yamba, V. Bawa. (1995). Permanent Pilgrims: The Role of Pilgrimage in the Lives of West African Muslims in the Sudan. Washington, DC: Smithsonian Institute Press.

Zawawi, Sharifa M. (2005). Kanga: The Cloth That Speaks. New York: Azaniya Hills Press. 